\title{
NATUREZA JURÍDICA DA OUTORGA ONEROSA DO DIREITO DE CONSTRUIR E DE SUA CONTRAPRESTAÇÃO COMO COMPENSAÇAO URBANÍSTICA
}

\section{LEGAL NATURE OF THE ONEROUS GRANTING OF THE RIGHT TO BUILD AND ITS CONSIDERATION AS URBAN COMPENSATION}

\author{
Luciane Martins Carneiro de Sousa ${ }^{1}$
}

\section{Resumo}

O presente trabalho busca discutir a natureza jurídica da outorga onerosa do direito de construir. $\mathrm{O}$ método de trabalho é a análise dogmática do instituto previsto no Estatuto da Cidade, sua revisão bibliográfica e sua diferenciação conceitual de institutos jurídicos afins. Para investigar o tema, debruça-se primeiramente sobre a noção de função social da propriedade com requisitos próprios, estabelece os pressupostos da outorga onerosa do direito de construir e se discute sua natureza jurídica de limitação urbanística ao direito de propriedade, em razão da função social de ordenamento do espaço urbano. Por fim, analisa a natureza jurídica da contraprestação a ser ofertada pelo particular na outorga onerosa do direito de construir, e depois estabelece a diferença desta para com os conceitos de taxa e preço público, e propõe que esta seja configurada como espécie de compensação urbanística, analogamente à compensação ambiental.

Palavras-chave: Direito de propriedade. Função social. Limitações urbanísticas. Zoneamento urbano. Outorga onerosa do direito de construir.

\begin{abstract}
This paper discusses the legal nature of onerous grant of the right to construct. The working method is the dogmatic analysis of the institute in the City Statute, a literature review and a conceptual differentiation of related legal institutions. To investigate the issue, focuses primarily on the social function of property, with its own requirements, establishes the presuppositions of onerous grant of the right to construct and discusses his legal urban limitation to property rights, due to the social function use of urban space. Finally, it analyses the legal nature of the consideration to be offered by the particular in the onerous grant of the right to construct, and then makes the difference for this with the concepts of tax and public price and proposes that it be set up as sort of urban compensation, similar to environmental compensation.
\end{abstract}

Keywords: Property right. Social function. Urban limitations. Urban zoning. Onerous grant of the right to construct.

\footnotetext{
1 Mestre em Direito da Cidade pela Universidade do Estado do Rio de Janeiro - UERJ. E-mail: luciane.rube@gmail.com
} 


\section{INTRODUÇÃO}

O presente trabalho se propõe a examinar o instituto da outorga onerosa do direito de construir, instituto positivado no Estatuto da Cidade em seus artigos 28 a 31, e investigar a natureza jurídica da referida outorga onerosa e a natureza jurídica da contraprestação a ser paga pelo beneficiário da mesma ao Município.

O instituto da outorga onerosa trouxe a lume uma importante discussão a respeito do direito de propriedade do imóvel urbano e sobre os poderes exercidos pelos proprietários, uma vez que tais bens devem ser utilizados também em razão de um interesse coletivo.

O instituto da outorga onerosa a ser examinado extrapola a noção do bem sujeito à vontade do proprietário; os poderes de usar, gozar e usufruir a coisa têm sentido amplo e incluem sujeitos difusos da coletividade. Por exemplo, o direito de o proprietário construir em um terreno seu depende, além da licença para construir, dada pelo Município, da adequação do bem aos padrões urbanísticos sociais, para garantir uma sociedade mais justa, na medida em que faz com que aquele que suprime o direito de bens difusos de todos pague pela supressão.

Diante deste cenário, o direito tem procurado encontrar soluções para a ordenação da cidade, como o planejamento urbano, a regulação do uso do solo, a ordenação do sistema viário, os zoneamentos, a estipulação de áreas non aedificandi, o parcelamento, a edificação e utilização compulsórias, o direito de preempção, o direito de superfície e a outorga onerosa do direito de construir, que é uma forma de regulação do espaço construído.

Todo direito tem custos, e, como o bem-estar do ambiente urbano é direito difuso, direito de todos, se alguém usufruir de benefícios que outros não têm, e estes benefícios acarretarem a supressão de um direito geral, então este particular que o obteve deve pagar por ele. Desta forma, ele estará devolvendo para a sociedade o custo do ônus imposto a todos em benefício de um, pois o simples fato da alteração negativa da totalidade do ambiente urbano circundante já importa utilização diferenciada e, consequentemente, o dever de compensar os demais.

Para a definição da natureza jurídica do instituto da outorga onerosa do direito de construir e de sua respectiva contraprestação, para chegar a uma conclusão, discorrer-se-á brevemente sobre poder de polícia, limitação administrativa e licença, especificadamente a licença para construir, e também sobre as categorias do tributo e do preço público.

Por fim, será vista a natureza jurídica da outorga onerosa do direito de construir e a natureza jurídica da contraprestação na outorga onerosa do direito de construir. 


\section{O SURGIMENTO DA NOÇÃO DE FUNÇÃO SOCIAL DA PROPRIEDADE}

Por muito tempo, prevaleceu a noção de direito de propriedade inspirada na Revolução Francesa. Num primeiro momento, logo após a Revolução, a liberdade em relação à propriedade era necessária para evitar os abusos cometidos, correspondendo à quebra de um sistema de exploração da maioria pela minoria. Contudo, com o aumento da população e, consequentemente, com o aumento das necessidades sociais, a interpretação que se fazia do direito de propriedade já não atendia os anseios da sociedade, diante da acumulação capitalista dos bens de produção, produzindo rompimento dos princípios da própria Revolução matriz, originando desigualdades e exploração (TORRES, Marcos Alcino de Azevedo. 2008. p. 162)²

Ocorreu uma evolução na noção de propriedade como direito natural para a ideia de propriedade função social. Já não permanece na legislação contemporânea a noção de propriedade como direito absoluto que dominava o direito outrora. Originariamente, eram conferidas prerrogativas que garantiam o pleno direito sobre o bem em detrimento da coletividade. Com os anseios e necessidades da sociedade, a propriedade moderna tende cada vez mais a se subordinar ao bem comum e às inúmeras restrições e limitações que se fazem hoje ao seu livre exercício, imprimindo à propriedade um caráter mais dinâmico e justo. O direito de ter propriedade está cada vez mais ligado à noção de boa gestão em um valor social de bem comum e atinente ao bem-estar coletivo.

Conforme leciona Savatier a respeito:

O proprietário não é mais o homem tendo direitos absolutos sobre seu bem, com poderes de destruí-lo e de deixá-lo inativo. Há hoje, na maior parte dos países, e notadamente na França, uma série de leis que obrigam o proprietário a consagrar sua propriedade ao interesse geral; que the impedem de destruí-la em certos casos; ou mesmo de modificá-la; que o proíbem, muitas vezes, de vendê-la e dispor dela livremente; que o obrigam a torná-la útil; que o tornam enfim, responsável pelos danos causados por seus bens. O proprietário aparece, assim, mesmo tanto quanto o indivíduo no interior do direito civil, como encarregado de um serviço público (SAVATIER, René. 1950. p. 13) ${ }^{3}$.

Apesar de a propriedade conferir um domínio pleno, não se pode abusar deste poder em prejuízo da coletividade. A evolução social demonstrou a justificação de um interesse maior que o interesse privado, não podendo a propriedade ceder aos caprichos de seu dono, diante de tanta

\footnotetext{
2 TORRES, Marcos Alcino de Azevedo. A propriedade e a posse, um confronto em torno da função social. 2. ed. Rio de Janeiro: Lumen Juris, 2008. p. 162.

${ }^{3}$ SAVATIER, René. Du droit civil au droit public. 2. ed. Paris: LGLD, 1950. p. 13.
} 
miséria e necessidades no mundo. A propriedade não pode permanecer inculta à espera de valorização. A noção de solidariedade que antes restava esquecida floresce diante das privações do mundo. Os valores individuais não podem prosperar diante da opressão da massa, privada de bens mínimos existenciais e excluída do direito à terra.

Houve um efetivo impacto do princípio sobre a propriedade, principalmente a urbana, e sobre seus efeitos quanto à definição do seu perfil. A propriedade não consubstancia mais um direito subjetivo justificado exclusivamente pela sua origem, mas permanece como direito exclusivamente à medida que se atente a que seu fundamento é inseparável da consideração do seu uso. Daí não poder a propriedade ser usada de modo contrário à utilidade social, preservandose o direito do proprietário somente enquanto o seu uso contrário ao interesse social não ocorrer (GRAU, Eros Roberto. 1983. p. 65) ${ }^{4}$.

O princípio da função social da propriedade, desta sorte, passa a integrar o conceito jurídico-positivo de propriedade, de modo a determinar profundas alterações estruturais.

As limitações urbanísticas são necessárias não somente para adequar a propriedade às leis de planejamento urbano e zoneamento, mas também para fazer com que a propriedade cumpra seu papel social. Ressalta José Afonso da Silva que:

O artigo 182, §2으, da Constituição menciona expressamente a propriedade urbana no contexto de normas e planos urbanísticos, vinculando sua função social à ordenação da cidade expressa no Plano Diretor. Assim, a utilização do solo urbano fica sujeita às determinações de leis urbanísticas e ao Plano Diretor. Desta forma, a função social da propriedade urbana somente estará sendo atingida se o seu uso estiver de acordo com as limitações urbanas impostas, pois este é o instrumento usado pelo Poder Público para adequar a propriedade às leis urbanísticas. Somente assim a propriedade urbana estará cumprindo a função social.(SILVA, José Afonso da. 2010. p. 75) $)^{5}$

A atividade urbanística constitui uma função pública da Administração e é a ela quem compete determinar a ordenação das cidades, vincular a livre iniciativa e os direitos a serem exercidos sobre a propriedade. O solo urbano é regulado pelos planos e normas urbanísticas, de acordo com as necessidades da urbe, que lhe fixam o destino a que fica vinculado o proprietário.

Esse destino consiste primordialmente na ordenação do terreno e na sua funcionalização social. A utilização do solo urbano pelos proprietários depende primeiramente da predeterminação dada pela legislação e planos urbanísticos.

\footnotetext{
${ }^{4}$ GRAU, Eros Roberto. Direito urbano, regiões metropolitanas, solo criado, zoneamento e controle ambiental, projeto de lei de desenvolvimento urbano. São Paulo: Revista dos Tribunais, 1983. p. 65.

${ }^{5}$ SILVA, José Afonso da. Direito urbanístico brasileiro. 6. ed. São Paulo: Malheiros, 2010. p. 75.
} 
Acresce-se a isto o fato de que a função social da propriedade pode fundamentar destinos diversos para os terrenos, determinando a atividade dos respectivos proprietários e o conteúdo de seu direito. Com tal fundamento, é lícito determinar, por exemplo, a inedificabilidade absoluta ou relativa de certos terrenos que, em princípio, seriam edificáveis, bastando para tanto a Administração afirmar não ser conveniente ou oportuno determinada construção em respectiva área, em razão da estética urbana, da densidade, por motivos ambientais ou outros, e isto sem falar em desapropriação. O que se deseja salientar é que o direito de propriedade privada não pode superpor-se ao preceito constitucional da sua função social, ao ponto de impor a faculdade de edificar onde o interesse público aconselha a inedificabilidade.

Devem ainda ser mencionadas as limitações urbanísticas referentes ao uso, de acordo com leis de zoneamento, que determinam os diversos tipos de usos em cada área, ocupação do terreno, índices urbanísticos, coeficiente de aproveitamento, taxa de ocupação, recuos, gabarito, circulação, características arquitetônicas, etc.( SILVA, José Afonso da. 2010. p. 82) ${ }^{6}$

A ideia subjacente é a de que o valor da unidade do solo urbano, portanto, em que se expressa economicamente o direito de propriedade, corresponde a um padrão, que deve ser igual para todos os proprietários. Aquele que exceder este padrão, apoderando-se de um direito coletivo, deve pagar, pois suprimiu um bem de todos em favor de um direito individual.

\section{CIDADES SUSTENTÁVEIS}

O Estatuto da Cidade reconheceu a existência de interesses transindividuais coletivos e difusos na ordem urbanística, quando impõe como uma de suas diretrizes a adoção de padrões de produção e consumo de bens e serviços, e de expansão urbana, compatíveis com os limites da sustentabilidade ambiental, social e econômica. O Estatuto não mais admite a atuação irresponsável dos órgãos encarregados da política urbana municipal, licenciando empreendimentos sob pressão das construtoras ou dos empreendedores individuais, sem se preocupar com o meio ambiente, sem um planejamento sustentável.

O direito a cidades sustentáveis é de fato um direito fundamental das populações urbanas e deve prevalecer em toda a política urbana, devendo haver um equilíbrio entre o bem-estar dos cidadãos e o desenvolvimento da cidade, de forma que todos possam viver harmoniosamente.

\footnotetext{
${ }^{6}$ SILVA, José Afonso da. Direito urbanístico brasileiro. 6. ed. São Paulo: Malheiros, 2010. p. 82.
} 
Deve-se sempre ter em vista, no planejamento das cidades, as presentes e futuras gerações. Todos os direitos relacionados ao desenvolvimento urbano, bem como o processo de formação de cidades sustentáveis, devem visar ao bem-estar social. A cidade sustentável é uma conjugação dos fatores do meio ambiente urbano com os do meio ambiente natural.

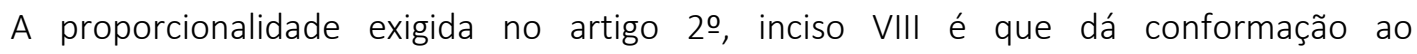
desenvolvimento sustentável. Exigir desenvolvimento sustentável significa condicionar a evolução da cidade ao respeito que se deve dispensar aos fatores socioeconômicos e ambientais, numa postura urbanística de almejado equilíbrio.

O proprietário do bem fica condicionado a um comportamento ativo. Desta forma, a função social e a proteção ambiental do ambiente urbano passam a integrar o próprio conteúdo do direito de propriedade. O uso da propriedade no desenvolvimento de atividades econômicas deverá, além de atender às necessidades particulares do proprietário, ir ao encontro dos interesses da sociedade e harmonizar-se com a preservação dos recursos nela existentes. O direito à livre iniciativa da atividade econômica é limitado pelo interesse da coletividade e da utilização racional dos recursos difusos.

O direito busca soluções para a ordenação da cidade compatíveis com o desenvolvimento econômico. Para isso, fazem-se necessários o planejamento urbanístico, a regulação do uso do solo, a ordenação do sistema viário, os zoneamentos, a estipulação de áreas non aedificandi, o parcelamento, edificação e utilização compulsórios, o direito de preempção, o direito de superfície e a outorga onerosa do direito de construir, dentre outros.

Quanto ao instituto da outorga onerosa do direito de construir, procura o direito conciliar desenvolvimento com responsabilidade social. Anteriormente, poderia um particular construir sem preocupação com o ônus imposto à sociedade em razão da construção acima de um potencial igualitário; agora, há uma percepção que se sobrepõe ao interesse do particular e aos interesses especulativos, havendo a preocupação com o bem-estar social e com a reversão de um custo adicional imposto à sociedade, sendo que este custo deve ser compensado de alguma forma, numa tentativa de melhorar a vida urbana em razão deste ônus. Assim, veio o Estatuto da Cidade positivar a outorga onerosa do direito de construir, instituto que tem como fundamentos os princípios do solo criado. 


\section{A OUTORGA ONEROSA DO DIREITO DE CONSTRUIR}

Embora a vigente Constituição queira o direito de propriedade e o garanta, pode e deve a lei restringir o uso e a disposição da mesma, uma vez que existem várias atividades, construções, utilização do terreno para fins de lazer, usos diversos, que podem ser exercidos sobre o solo urbano. A possibilidade e/ou o efetivo exercício de tais atividades sobre aquele suporte conferem ao solo urbano um valor, que deve ser considerado independentemente de qualquer causa exógena à propriedade, e que se expressa como componente econômico da propriedade, objeto de proteção jurídica. Tal componente econômico pressupõe um volume de utilização mínimo da unidade de solo urbano, que não poderá ser reduzido quando da fixação do padrão, isto é, do coeficiente único de aproveitamento, o qual deve, nas zonas urbanas, ser a expressão do volume máximo de utilização da propriedade, conforme o princípio da sua função social, sem que do proprietário possa ser exigida qualquer contrapartida específica (GRAU, Eros Roberto. São Paulo, 1983. p. 77) $)^{7}$.

Verificado que a criação de solos artificiais, ou seja, a criação de solo acima do coeficiente permitido, implica, inevitavelmente, um acréscimo de demanda por serviços públicos de infraestrutura, cujo custo deve ser distribuído por toda a comunidade, nada mais coerente com o princípio da justiça social que a outorga onerosa do direito de construir.

O Município é responsável pelo controle do uso do solo urbano conforme o interesse social, por consubstanciar matéria de interesse local, cabendo, por isto, àquele a competência para a determinação do coeficiente único de aproveitamento. Cabe ao Município fixá-lo, no exercício de suas atribuições inerentes à preservação do interesso social a nível local. O Município, ao definir esse coeficiente, aplicável à totalidade do seu território, não invade área de competência da União, eis que não estará regulando a propriedade no seu aspecto civil, mas sim no seu aspecto urbanístico (GRAU, Eros Roberto. São Paulo, 1983. p. 77) .

Considerando-se que o direito de propriedade assegurado na Constituição é condicionado pelo princípio da função social da propriedade, não deve assim exceder determinada extensão de uso e disposição, cujo volume é definido segundo a relevância do interesse social, e quem o exceder deve contribuir para os gastos públicos adicionais custeados por toda a sociedade através de tributos.

\footnotetext{
${ }^{7}$ GRAU, Eros Roberto. Direito urbano, regiões metropolitanas, solo criado, zoneamento e controle ambiental, projeto de lei de desenvolvimento urbano. São Paulo: Revista dos Tribunais, 1983. p. 77.

${ }^{8}$ Ibidem. p. 79.
} 
É convicção deste trabalho que a outorga onerosa do direito de construir foi elaborada como instituto jurídico com base nos fundamentos do solo criado, uma noção desenvolvida com base nos princípios da solidariedade, justiça social e função social. A outorga onerosa do direito de construir é um novo instrumento da política urbana instituído pelo Estatuto da Cidade. As normas que regulam o instituto geram uma espécie de solo criado, ou seja, um espaço edificável acima do coeficiente de aproveitamento (SILVA, José Afonso. 2010. p. 264) ${ }^{9}$.

Isto só pode ocorrer onde a lei de zoneamento assim o permitir, porque é imprescindível a vinculação do instituto com o zoneamento urbano. O Estatuto acolhe esses mecanismos no artigo 28, § 3으, onde estabelece que o Plano Diretor definirá os limites máximos a serem atingidos pelos coeficientes de aproveitamento, considerando a proporcionalidade entre a infraestrutura existente e o aumento de densidade esperado em cada área.

Essas constatações demostram que a lei acolheu alguns dos mecanismos que integram o conceito de solo criado, como a vinculação com o zoneamento, a proporcionalidade entre infraestrutura e aumento de densidade em cada área e a onerosidade do solo criado.

Cabe ao Município o poder jurídico de conferir o direito de construir acima dos limites legais, através do Plano Diretor, pois se deve levar em consideração a proporcionalidade entre a infraestrutura urbana existente e o aumento de densidade esperado em cada área. Isto significa que o proprietário ou o titular do direito de construir estará sujeito a consentimento do órgão municipal competente (CARVALHO FILHO, José dos Santos. Comentários, 2009. p. 201) ${ }^{10}$.

De acordo com o Estatuto da Cidade, o Município, através do Plano Diretor, poderá fixar áreas em que será viável ao proprietário ou ao titular do direito empreender a realização de edificações acima do coeficiente de aproveitamento básico adotado, desde que o interessado se prontifique a oferecer contrapartida pelo benefício recebido.

Quando na área for permitida construção, afiguram-se duas situações: a construção poderá ser realizada dentro dos limites traçados pelo coeficiente básico de aproveitamento ou com base em potenciais adicionais. Tanto no primeiro caso (construção no limite do coeficiente de aproveitamento), como no segundo (construção em potencial adicional, pagando-se o preço respectivo pelo coeficiente adicional), haverá a necessidade de licença para construir. A licença será sempre ato vinculado, pois, uma vez preenchidos os requisitos para sua concessão, deverá ser

\footnotetext{
${ }^{9}$ SILVA, José Afonso. Direito urbanístico brasileiro. 6. ed. São Paulo: Malheiros, 2010. p. 264.

${ }^{10}$ CARVALHO FILHO, José dos Santos. Comentários ao Estatuto da Cidade. 3. ed. Rio de Janeiro: Lumen Juris, 2009. p. 201.
} 
deferida, tendo o proprietário direito subjetivo de erguer a construção como concedida pela licença. Em ambos os casos, está presente o exercício do poder de polícia fiscalizatório, mas, uma vez concedida a licença, o direito de construir em si já foi gerado.

Há de ser observado que uma coisa é a análise prévia da possibilidade de construção adicional para a área mediante a outorga onerosa do direito de construir, outra é a concessão da licença, que somente verificará o preenchimento dos requisitos previamente estabelecidos, numa posição simplesmente fiscalizatória, e não de análise da possibilidade de potencial adicional na respectiva área objeto da licença. A licença para construir é ato vinculado, enquanto a submissão de uma determinada área ao mecanismo de aumento do potencial construtivo por outorga onerosa é ato discricionário do Município.

Para que haja possibilidade da outorga na respectiva área, necessário se faz que, primeiramente, haja estudo do impacto de vizinhança e impacto ambiental para a localidade, de acordo com exigência do Estatuto da Cidade. Segundo, é preciso que haja previsão de possibilidade de acréscimo de potencial construtivo tanto no Plano Diretor como em lei municipal específica. Terceiro, caso se deseje construir acima do potencial básico, deve haver o pagamento da contraprestação, e a fórmula para o cálculo desta deve estar prevista em lei municipal específica, que estabelecerá as condições a serem observadas para a outorga.

O certo é que, na outorga onerosa, o deferimento é possível depois de preenchido os requisitos acima descritos, desde que haja previsão no Plano Diretor e em lei específica. Sendo assim, depois de possibilitada a outorga para uma área respectiva, haverá a vinculação quanto à licença, vale dizer, mesmo quando o direito de construir for pretendido além dos limites do coeficiente básico de aproveitamento, continuará militando em favor do interessado a presunção de que a construção é compatível com a ordem urbanística, como ocorre no direito de construir dentro do coeficiente fixado. Isto ocorre porque o local onde é permitida a construção adicional já foi previamente previsto no Plano Diretor, e o estudo do impacto e acréscimos com infraestrutura ou análise da possibilidade de acréscimo já devem ter sido feitos.

Obviamente, se os agentes públicos responsáveis pela elaboração ou análise dos estudos de impacto entenderem que uma determinada área não comporta construções acima do coeficiente básico, simplesmente estas áreas não serão propostas para integrar aquelas indicadas como passíveis de outorga onerosa do direito de construir. Nestes últimos casos, não cabe falar em um direito a construir acima do coeficiente básico de aproveitamento. Repise-se: para haver direito 
à outorga onerosa, é necessário, ademais do cumprimento dos requisitos legais e da oferta de uma contraprestação, que antes a área seja passível de construções adicionais.

Uma última observação é a de que a permissão para construção acima do coeficiente de aproveitamento só pode ser concedida se ainda houver estoque de construção adicional para a respectiva área, este deve ter sido previsto anteriormente. Em caso de haver-se esgotado o estoque, a outorga onerosa não será permitida e, consequentemente, a licença para construção adicional não poderá ser concedida.

O Município, ao deferir a outorga onerosa, deve buscar um equilíbrio entre os espaços públicos e os espaços privados, de forma a estabelecer a verdadeira funcionalidade social da propriedade urbana, buscando também a compensação pelo uso exclusivo de um bem coletivo.

A propriedade e seu uso não devem ser olhados separadamente, mas sim como um todo, devendo a mesma ser utilizada de forma que integre a comunidade e a cidade. Desta forma, a utilização adicional de uma propriedade equipara-se a um privilégio que nem todos possuem. Sendo assim, deverá ser a comunidade em geral compensada com uma contrapartida, pois a propriedade possui uma função social que extrapola os interesses individuais. É esta função social que, ao ser exercida, funcionaliza o exercício do direito de propriedade e o legitima. Ademais, foram os tributos pagos genericamente por todos que tornaram possível haver maior investimento de infraestrutura na localidade, tornando possível o aumento adicional de potencial construtivo usufruído por determinado sujeito.

\section{Pressupostos para a outorga onerosa do direito de construir}

\section{Cálculo para cobrança}

Não há especificação quanto à fórmula de cálculo para cobrança da contraprestação da outorga onerosa no Estatuto da Cidade. No entanto, a Administração não pode ficar livre para cobrar o que bem entender, nem deve o valor corresponder ao custo-benefício, cobrado via taxa. Outrossim, a cobrança deve estar diretamente ligada à noção de função social da cidade.

Não há dúvida de que, na visão do contribuinte, a admissão de que a contrapartida seja definida como um tributo da espécie taxa ocasionaria um maior controle na cobrança da outorga, sendo que o tributo possui limitações estritas, como, por exemplo, a impossibilidade do confisco e as hipóteses de isenção, que devem estar previstas em lei. Ocorre, contudo, que o benefício da construção acima do potencial não tem essa finalidade, a de garantir segurança ao beneficiário, e 
sim a finalidade urbanística de compensação por afetar um direito difuso e de compensação pelo investimento adicional com infraestrutura, executado pela Administração em benefício de uns poucos. Por isto também se exige, conforme expresso no Estatuto da Cidade, o estudo do impacto de vizinhança e ambiental. Aqui necessário se faz recorrer ao princípio do justo equilíbrio do ambiente saudável que deve revestir tal pagamento.

Postas assim as coisas, a cobrança pode ser feita, desde que prevista em lei específica municipal, de acordo com os dados fornecidos no relatório prévio de impacto de vizinhança e impacto ambiental, exigidos pelo Estatuto da Cidade no artigo 4ㅇ, inc. VI. Elaborado o relatório, conforme o impacto da construção adicional gerado à cidade e a seus habitantes, o Município terá noção do quanto poderá ser cobrado do beneficiário.

\section{Contrapartida}

No caso de ser concedida a construção acima do potencial básico para a área, o Estatuto impõe a necessidade de contrapartida, vedando assim que a outorga do direito se faça gratuitamente. O Estatuto não deixou claro que tipo de contrapartida seria necessário. Em regra, a contrapartida deverá ser de ordem pecuniária, cabendo ao beneficiário pagar o valor correspondente ao benefício atribuído, mas é possível que, dependendo das necessidades e peculiaridades do Município, a contrapartida seja de outra espécie, como, por exemplo, doação de alguma área privada para o Município, ou parceria em projetos sociais de habitação para comunidades de baixa renda, podendo as hipóteses variar sobremaneira. (CARVALHO FILHO, José dos Santos. Rio de Janeiro. 2009. p. 212)11 . Contudo, a visão financista adotada quanto à outorga é reforçada ainda mais quando o artigo 30 do Estatuto da Cidade afirma que lei municipal específica estabelecerá a fórmula de cálculo para a cobrança.

Há controvérsia quanto à natureza jurídica da contrapartida a ser prestada pelo interessado. Para alguns, tem caráter tributário; para outros, tratar-se-ia de preço público, mas a posição adotada no presente trabalho é a de que se trata de uma compensação urbanística.

\footnotetext{
${ }^{11}$ CARVALHO FILHO, José dos Santos. Comentários ao Estatuto da Cidade. 3. ed. Rio de Janeiro: Lumen Juris, 2009. p. 212.
} 


\section{Aplicação dos recursos}

O artigo 31 do Estatuto afirma que os recursos auferidos com a adoção da outorga onerosa do direito de construir e de alteração de uso do solo urbano serão aplicados estritamente de acordo com as finalidades urbanísticas previstas nos incisos I a IX do artigo 26 daquela lei:

\section{Controle}

Para evitar desvios de finalidade e dilapidação indevida dos recursos e bens públicos, o Estatuto da Cidade, no artigo 52, inc. IV, inseriu outra hipótese de improbidade administrativa na Lei no 8.429, de 02.06.92.

Pelo novo dispositivo, o prefeito incorre em improbidade administrativa quando "aplicar os recursos auferidos com a outorga onerosa do direito de construir e de alteração de uso em desacordo com o previsto no artigo 31 desta Lei". Essa tipificação de conduta atribuída ao prefeito não exclui a de outros agentes, também qualificados como ímprobos. O que a lei deseja coibir é que os frutos de atividades públicas de cunho urbanístico sirvam para fins outros que não os inerentes à política urbana definida no Plano Diretor.

\section{NATUREZA JURÍDICA DA OUTORGA ONEROSA DO DIREITO DE CONSTRUIR}

Primeiramente, será necessário definir a natureza jurídica da outorga onerosa do direito de construir, para depois ser delimitada a natureza jurídica da contraprestação da outorga.

Ao analisar a outorga onerosa, foi constatado que a mesma se trata de uma limitação administrativa, limitação da propriedade para regulação do espaço urbano, para que a propriedade e o seu exercício se adequem e se condicione ao uso da propriedade imobiliária conforme o atendimento de sua função social.

É de se notar que a análise da área para a possibilidade da admissão da outorga onerosa do direito de construir em determinada região deve ser feita por agentes técnicos do Município, com base nos estudos de impacto de vizinhança e impacto ambiental. Assim, a decisão acerca da indicação ou não da outorga onerosa para uma área determinada é ato discricionário e de competência dos agentes, pois, mesmo que a região comporte, em tese, tal adensamento, é possível que os agentes municipais não recomendem, por meio de pareceres técnicos, a inserção da outorga onerosa naquela localidade. Caso o Poder Legislativo, fazendo tábula rasa dos estudos e pareceres técnicos, resolva-se por aceitar a outorga naquela área, admitindo-a no Plano Diretor,

\footnotetext{
Revista de Direito da Cidade, vol. 08, no 1. ISSN 2317-7721 pp.193-224 204
} 
uma vez inserida a localidade em zona que admite a outorga onerosa, o ato de licenciamento será vinculado, cabendo à Administração tão-somente a análise do preenchimento dos requisitos para a sua concessão em área concreta.

A intervenção que aqui nos interessa é a intervenção restritiva, por ser aquela em que o Estado impõe restrições e condicionamentos ao uso da propriedade, sem, no entanto, retirá-la de seu titular. São modalidades de intervenção restritiva a servidão administrativa; a requisição; a ocupação temporária; as limitações administrativas e o tombamento (CARVALHO FILHO, José dos Santos. Rio de Janeiro. 2007.p. 847) ${ }^{12}$.

Para José dos Santos Carvalho Filho:

Limitações administrativas são determinações de caráter geral, através das quais o Poder Público impõe a proprietários indeterminadas obrigações positivas, negativas ou permissivas, para o fim de condicionar as propriedades ao atendimento da função social. [...] No caso de limitações administrativas o Poder Público não pretende levar a cabo qualquer obra ou serviço público. Pretende, ao contrário, condicionar a propriedade à verdadeira função social que dela é exigida, ainda que em detrimento dos interesses individuais dos proprietários. [...] Muitas limitações administrativas têm sua origem em leis e atos de natureza urbanística. A própria Constituição destina capítulo específico à política urbana (arts. 182 e 183) e contempla institutos apropriados à sua execução. A Lei no 10.257 , de 10/07/2001 - o Estatuto da Cidade - institui diversos instrumentos que se configuram como limitações administrativas. A manifestação volitiva do Poder Público no sentido das limitações pode ser consubstanciada por leis ou por atos administrativos normativos. Serão eles sempre gerais, porque, contrariamente ao que ocorre com as formas interventivas anteriores, as limitações não se destinam a imóveis específicos, mas a um grupamento de propriedades em que é dispensável a identificação. Há, pois, indeterminabilidade acerca do universo de destinatários e de propriedades atingidas pelas limitações. [...] a natureza jurídica das limitações [...] se trata de atos legislativos ou administrativos de caráter geral, que dão o contorno do próprio direito de propriedade. É nesse sentido que os autores as colocam entre as formas de intervenção do Estado na propriedade. O fundamento básico das limitações administrativas não difere em última análise do que dá escora às demais formas interventivas. A propriedade deve atender a sua função social, dando prevalência ao interesse público sobre os interesses particulares. [...] Em relação, porém, às limitações administrativas, é de toda a oportunidade invocar outro fundamento, normalmente apontado pelos estudiosos: o exercício do poder de polícia. De fato, o poder de polícia encerra exatamente a prática de atos administrativos que restringem e condicionam a liberdade e a propriedade, com vistas ao

${ }^{12}$ CARVALHO FILHO, José dos Santos. Manual de direito administrativo. 17.ed. Rio de Janeiro: Lumen Juris, 2007.p. 847. 
interesse coletivo.( CARVALHO FILHO, José dos Santos. Rio de Janeiro, 2007.p. 863-866) $)^{13}$

Voltando os olhos para a realidade que interessa a este trabalho (o espaço urbano), as limitações urbanísticas nada mais são que espécie de limitação administrativa voltada para a organização do espaço urbano, por meio de mecanismos como a regulação do uso do solo, as limitações ao potencial construtivo, a edição de normas para as construções de modo a garantir padrões mínimos de conforto, segurança e higiene, tudo isto com o objetivo de afiançar o bem estar dos cidadãos que habitam as cidades.

Ressalte-se que a atividade edilícia é regulada por dois tipos de normas: normas definidoras de controle técnico das construções e normas de controle urbano da atividade construtiva. As primeiras regulam as construções individualmente consideradas e se propõem a assegurar a correspondência com as exigências de higiene, segurança, estética. As segundas têm em mira a construção, porém como parte de um conjunto. São medidas que visam a realizar a adequação da atividade construtiva dos particulares ao modelo de assentamento urbano previsto para cada zona ou área.

A licença edilícia é informada por alguns princípios gerais:

1. Necessidade, o interessado é obrigado a requerê-las nos casos em que o exercício da atividade as exija. Ela é indispensável, insubstituível, não podendo a Administração dispensá-las nem substituí-las por outra exigência ou compensação;

2. Caráter vinculado, não pode ser negada quando o requerente demonstra ter preenchido todas as exigências e requisitos previstos em lei;

3. Transferibilidade, transmite-se automaticamente aos sucessores com a só alienação do imóvel; e

4. Autonomia, não tem efeito no que tange às relações privadas do requerente. A outorga da licença não prejulga questões de domínio, nem prejudica direito de terceiros. As questões de domínio são questões civis e não é de sua competência. (SILVA, José Afonso da, São Paulo, 2010. p. 435) ${ }^{14}$.

\footnotetext{
${ }^{13}$ CARVALHO FILHO, José dos Santos. Manual de direito administrativo. 17. ed. Rio de Janeiro: Lumen Juris, 2007.p. 863-866.

${ }^{14}$ SILVA, José Afonso da. Direito urbanístico brasileiro. 6. ed. São Paulo: Malheiros, 2010. p. 435.
} 


\section{NATUREZA JURÍDICA DA CONTRAPRESTAÇÃO DA OUTORGA ONEROSA DO DIREITO DE CONSTRUIR}

Antes de concluir qual a natureza jurídica da contraprestação da outorga onerosa, devemse analisar algumas das posições adotadas, uma vez que alguns autores acreditam ser a contraprestação um tributo na modalidade taxa, enquanto outros afirmam se tratar de preço público. Ao final, será apresentada a posição adotada por este trabalho e será justificado porque não se concorda aqui seja com quem adota a posição que qualifica a contraprestação como modalidade tributária, seja com quem a assemelha a preço público.

\section{Razão de a contraprestação da outorga onerosa não ser considerada taxa}

Primeiramente, verifica-se, como já dito, que a outorga onerosa do direito de construir é uma limitação ao direito de propriedade para regulação do espaço urbano, fiscalizada pelo poder de polícia do Estado para que a propriedade e o seu exercício se adequem ao atendimento da função social, para o respeito ao condicionamento do uso da propriedade imobiliária a fim de que seja atendida sua função social.

No entanto, a contrapartida da outorga onerosa não pode ser considerada tributo da espécie taxa, e demonstra-se agora o porquê disto. Como já esclarecido, os agentes públicos, através dos relatórios do estudo de impacto ambiental e do estudo de impacto de vizinhança e possibilidade de adensamento, são os responsáveis pela emissão de parecer técnico recomendando a outorga para uma região. A decisão dos agentes de indicar ou não a área é discricionária, à luz da análise feita com base nos estudos de impacto. Contudo, se o legislativo municipal autorizar a outorga para aquela área no Plano Diretor, a concessão da licença para construir, preenchidos os requisitos exigidos do particular, constitui ato administrativo vinculado, com natureza de ato meramente fiscalizatório, em razão do poder de polícia.

Em função disso, a contraprestação originária da outorga onerosa não pode ser cobrada via taxa, pois esta diz respeito tão-somente à concessão da licença mediante a emissão de alvará. Este pagamento de taxa para concessão da licença existe em qualquer caso, sendo o pedido para construção acima do potencial construtivo ou não. A outorga onerosa, por sua vez, está ligada à função social da propriedade, ao uso adicional do ambiente urbano, direito de todos, e à adequação dos equipamentos urbanos em razão do adensamento extraordinário permitido. 
Ademais, conforme o art. 3ำ do CTN, tributo é toda prestação pecuniária compulsória, em moeda ou cujo valor nela se possa exprimir, que não constitua sanção de ato ilícito, instituída em lei e cobrada mediante atividade administrativa plenamente vinculada. Se a prestação é pecuniária, seu valor só há de poder se expressar em moeda, não se devendo entender que a possibilidade de a obrigação tributária poder extinguir-se por outros modos que não a entrega em dinheiro subtrairia à prestação devida a expressão pecuniária ou monetária.

Apesar de o instituto da outorga ter adotado a visão financeira e não urbanística do solo criado, devendo a contraprestação ser preferencialmente paga em dinheiro, nada impede que o Poder Público municipal disponha de forma diferente. É possível que a lei municipal específica admita o pagamento da contraprestação mediante doação ao Município de uma área para, por exemplo, ser destinada a uma praça pública.

Luiz Henrique Antunes Alochio, que se filia à corrente que acredita configurar a contraprestação da outorga onerosa uma taxa, consegue perceber este problema, pois afirma que tal contraprestação somente seria taxa no caso de ser paga em dinheiro. Mas consegue vislumbrar que a contraprestação da outorga onerosa pode também ser adimplida em imóveis, como espaços para play grounds, jardins ou obras de melhoria da malha viária. Neste caso, não desejando admitir que a teoria da taxa não se adequa a todos os casos de contraprestação da outorga onerosa, parece simplesmente querer negar a realidade, ao afirmar que os casos de contraprestação paga em imóveis não constituem objeto de sua investigação, uma vez que não cabem em sua teoria da contraprestação como uma taxa. (ALOCHIO, Luiz Henrique Antunes. Rio de Janeiro, 2005. p. 161) ) $^{15}$

Contudo, se a definição da natureza jurídica da contraprestação da outorga onerosa como taxa não é predicável de todos os casos de contraprestação, significa que a teoria não cumpre bem sua função de explicar o fenômeno estudado.

Outro inconveniente quanto à escolha da taxa para caracterizar a contraprestação seria o caso de que o valor cobrado através de taxas deveria abranger somente o custo-benefício. Esse é o grande princípio de justiça que as informa. O princípio do custo-benefício vem a significar que a receita não pode ser considerada independentemente da despesa, de modo que à prestação de serviços públicos deve corresponder a remuneração equivalente, ou, dito de outra forma, cada cidadão deve despender a título de pagamento dos tributos específicos e divisíveis uma soma de dinheiro exatamente proporcional ao benefício público que receber. Contudo, parece ser que a

\footnotetext{
${ }^{15}$ ALOCHIO, Luiz Henrique Antunes. Do solo criado, outorga onerosa do direito de construir: instrumento de tributação para a ordenação do ambiente urbano. Rio de Janeiro: Lumen Juris, 2005. p. 161.
} 
contraprestação na outorga onerosa deve abranger algo mais que o mero custo-benefício. O valor aqui é um benefício monetário que inclui não só o custo com investimentos em obras para suportar o acréscimo de adensamento urbano, como deve abranger uma contraprestação em razão da supressão de um direito difuso ao uso do ambiente urbano saudável, à fruição individual de um bem coletivo.

A contraprestação da outorga onerosa tem por fim o equilíbrio entre os espaços públicos e os espaços privados gerados com o ato de construir e a compensação pelo uso individual de um direito difuso. Ocorre que o equilíbrio entre espaços públicos e espaços privados é parte essencial do instituto do solo criado e da outorga onerosa, e este reequilíbrio busca na verdade algo exógeno: além do reequilibrio, uma funcionalização social.

Ademais, afirma José Afonso da Silva que:

Os princípios urbanísticos, especialmente o princípio da Justa Distribuição do ônus da Urbanização, e o princípio da afetação das mais valias ao custo da urbanização, segundo o qual os proprietários dos terrenos devem satisfazer os gastos da urbanificação, dentro dos limites do benefício dela decorrente para eles, como compensação pela melhoria das condições de edificabilidade que dela deriva para seus lotes, se distanciam do custo-benefício específico das taxas.( SILVA, José Afonso da.São Paulo, 2010. p. 45) ${ }^{16}$

Assim, conclui-se que devem ser observados os critérios de repartição de ônus e benefícios entre os cidadãos.

Outrossim, o tributo da modalidade taxa de polícia aplicável à espécie diz respeito à licença para construir, licença esta que obrigatoriamente deverá existir, seja para construção acima do potencial básico, seja mesmo para o potencial básico permitido. Por sua vez, a compensaçãocontraprestação não se confunde com a taxa de polícia cobrada pelo licenciamento, já que não é exigida dos empreendedores pelo fato de utilizarem a máquina estatal de polícia. A compensaçãocontraprestação, por sua vez, não apresenta o caráter retribuído próprio das taxas, por se tratar de uma forma de reparação de danos a que está sujeito o empreendedor e não uma forma de remuneração do Poder Público por atividade por ele exercida, conforme se verá em detalhes mais abaixo. Tampouco exibe natureza jurídica de taxa de serviço público, pois a mesma serve para remunerar um serviço público específico e divisível, prestado ao contribuinte ou posto à sua disposição.

\footnotetext{
${ }^{16}$ SILVA, José Afonsoda.Direito urbanístico brasileiro. 6. ed.São Paulo: Malheiros, 2010. p. 45.
} 
$\underline{\text { Razão de a contraprestação da outorga onerosa não ser considerada preço }}$ público

Alguns autores defendem a natureza contratual da outorga onerosa do direito de construir, e que a contrapartida, em razão do contrato, seria preço público.

Primeiramente deve-se definir o que seria o preço público. Preço público é o valor pago pelo particular ao Poder Público, quando facultativa e espontaneamente adquire bens, aufere vantagens, ou se utiliza de serviços públicos ou de utilidade pública.

Preço público é receita originária, paga de forma voluntária, visto que o Estado atua como particular na cobrança do mesmo. É prestação exigida pelo Estado ou por quem Ihe fizer às vezes, em regime de direito privado. Para a instituição de preço público, o regime é contratual e não compulsório, sendo obrigação assumida voluntariamente.

No caso de a outorga ser considerada contrato, o Poder Público agiria como particular, vendendo um bem seu. Ocorre que o adicional do potencial construtivo não é bem pertencente ao Poder Público; ele continua sendo do particular e, se o Poder Público dele se apossar para venda, deverá pagar uma indenização, pois se trata de expropriação. Se a Administração aliena um bem que a ela não pertence, ocorreu desapropriação de um bem que previamente não Ihe pertencia, e, neste caso, deve haver indenização. Ademais, mesmo que se considerasse que o potencial adicional construtivo não pertence ao indivíduo e sim à coletividade, este continuaria a não pertencer a Administração, mas configuraria antes um direito difuso, direito de todos (ALOCHIO, Luiz Henrique Antunes. Rio de Janeiro, 2005. p. 72) ${ }^{17}$.

A função social da propriedade veio impor mais limitações ao direito de propriedade. Embora o direito de construir continue sendo do proprietário do terreno, este, para construir acima do coeficiente indicado, deve adquirir o adicional construtivo como um meio de contribuir com os gastos que a sociedade terá com este adicional, por usá-lo de forma diferenciada das demais pessoas e onerar mais o Poder Público e a sociedade em razão da fruição de um bem difuso, devendo, pois, pagar a contraprestação.

Sendo assim, não procede o entendimento de Eros Roberto Grau, quando afirma que o Poder Público municipal apenas pode alienar direito de criar solo quando tais coeficientes já se encontrem na esfera de disposição do Município. Para este autor, quando o setor público negocia

\footnotetext{
${ }^{17}$ ALOCHIO, Luiz Henrique Antunes. Do solo criado, outorga onerosa do direito de construir: instrumento de tributação para a ordenação do ambiente urbano. Rio de Janeiro: Lumen Juris, 2005. p. 72.
} 
direito de criar solo, tal como o poderão fazer os particulares entre si, está alienando determinado bem, e não permitindo o exercício de atividade pelo poder de polícia. Para Eros Roberto Grau, o setor público estará operando a transferência de uma parte do seu patrimônio, mediante remuneração. Não haveria, na hipótese, nem prestação de serviço público, nem exercício de poder de polícia (GRAU, Eros Roberto.São Paulo, 1983. p. 81) ${ }^{18}$. No entanto, não poderá o Município que não tenha qualquer propriedade ou que não possua qualquer potencial construtivo em estoque

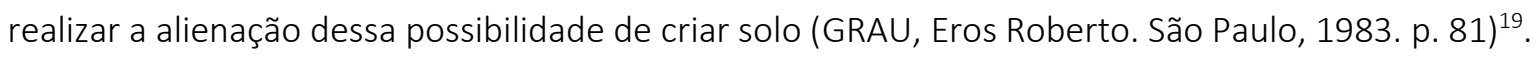

Como o nosso direito não adotou a tese, outrora consagrada na Itália, da separação da propriedade do direito de construir (com este último pertencendo ao Poder Público), de que modo poderia o Poder Público alienar bem a ele não pertencente? A única hipótese que se vislumbra seria a de que o Poder Público houvesse desapropriado o direito de construir sem pagamento da devida indenização, alienando-o depois a terceiro. Mas tal hipótese seria flagrantemente ilegal, pois a indenização, neste caso, seria devida ao proprietário expropriado de seu direito de construir.

\section{A natureza jurídica da contraprestação como compensação urbanística}

Adentra-se agora no instituto da compensação para se chegar à conclusão final a respeito da natureza jurídica da contraprestação da outorga onerosa do direito de construir. Para tanto, buscar-se-á compreender a ideia da compensação ambiental tal como definida na ótica do Supremo Tribunal Federal para se definir que a ratio iuris dessa é a mesma que informa a compreensão da natureza jurídica da contraprestação da outorga onerosa como uma compensação urbanística.

Definiu o Supremo Tribunal Federal no julgamento da ADI no. 3378/DF quanto à compensação ambiental, que se o exercício do direito de propriedade, através da construção de um grande empreendimento, causa significativo impacto ambiental, tornando mais escassa a fruição do meio ambiente pela coletividade presente e pelas gerações futuras, exsurge para o proprietário o dever de compensação, denominada compensação compartilhamento.

O Supremo Tribunal Federal, em decisão sobre o tema na ADI no 3.378/DF alterou a disciplina da compensação ambiental, tendo o STF julgado parcialmente procedente o pedido formulado na ADI no 3.378/DF, que tinha por objeto a declaração da inconstitucionalidade do

\footnotetext{
${ }^{18} \mathrm{GRAU}$, Eros Roberto. Direito urbano, regiões metropolitanas, solo criado, zoneamento e controle ambiental, projeto de lei de desenvolvimento urbano. São Paulo: Revista dos Tribunais, 1983. p. 81.

19 Ibidem. p. 80.
} 
artigo 36 e seus $\S \S 1$, 2ㅇ e 3ำ, da Lei $n \circ 0$ 9.985/2000. Assentou que o direito de propriedade se opera em função do direito de toda a coletividade a um meio ambiente ecologicamente equilibrado. Assim, se o exercício do direito de propriedade, através da construção de um grande empreendimento, causa significativo impacto ambiental, tornando mais escassa a fruição do meio ambiente pela coletividade presente e pelas gerações futuras, exsurge para o proprietário o dever de compensação, denominada compensação compartilhamento devida pela implantação de empreendimentos de significativo impacto ambiental (MOTA, Mauricio. Rio de Janeiro: Elsevier, 2009. p. 5$)^{20}$

A compensação deve ser fixada proporcionalmente ao impacto ambiental. Compete ao órgão licenciador fixar o quantum da compensação, de acordo com a compostura do impacto ambiental a ser dimensionado no relatório EIA/RIMA.

O Supremo Tribunal Federal entendeu que o artigo 36 da Lei no 9.985/2000 afirma o princípio do usuário pagador, um mecanismo de responsabilidade social pelos custos ambientais derivados da atividade econômica. A compensação ambiental não derivaria da contrariedade absoluta à regra jurídica ambiental, quando então poder-se-ia falar em ato ilícito stricto sensu e responsabilidade civil, mas sim da desconformidade para com o fim econômico-social para o qual o direito de propriedade foi instituído.

A decisão [do STF] entende que embora os bens tenham titularidades específicas, públicas ou particulares, em seu aspecto ambiental são de utilização comum de todos, por se tratar de um direito difuso e por ser o uso dos bens, ambientalmente considerados, comum a todos, é de responsabilidade de todos compartilhar as despesas para conservação, e se de alguma forma alguém vem a utilizar os recursos naturais ou afetou o ecossistema mais intensamente, a ponto de construir empreendimento que cause significativo impacto ambiental, cabe a este, na proporção da atividade por ele despendida apurada através de EIA/RIMA, compensar, na medida de sua utilização maior, os demais.

A inexistência de efetivo dano ambiental não importa em isenção do empreendedor de obrigação de partilha dos custos de medidas preventivas. Isso ocorre porque o princípio do usuário pagador implica que o só fato da alteração ambiental negativa da totalidade do meio ambiente circundante já importa em utilização diferenciada, e, consequentemente, no dever de compensar

20 MOTA, Mauricio. Função socioambiental da propriedade: a compensação ambiental decorrente do princípio do usuário pagador na nova interpretação do Supremo Tribunal Federal. In: MOTA, Mauricio (Org.) Função Social do Direito Ambiental. Rio de Janeiro: Elsevier, 2009. p. 5. 
os demais, dado o caráter de indivisibilidade do meio ambiente entre todos e também com as futuras gerações (MOTA, Mauricio. Rio de Janeiro, 2009. p. 5) 21 $^{21}$

Na compreensão de Mauricio Mota, a decisão do STF tenta conciliar o direito ao desenvolvimento econômico/livre iniciativa e a preservação do meio ambiente.

A decisão do STF, através de uma declaração parcial de inconstitucionalidade com redução de texto, suprimiu, ainda, a fixação de percentual mínimo sobre o custo do empreendimento, no montante de meio por cento dos custos totais previstos para a implantação do empreendimento, prevista no $\S 1$ o do artigo 36 da Lei № 9.985/2000. Essa disposição permite que o órgão licencidador defina o valor do financiamento compartilhado em estrita conformidade com os dados técnicos do EPIA/RIMA. Entendeu o Pretório Excelso que o custo do empreendimento não é o critério adequado para a determinação do quantum da compensação ambiental, mas sim o impacto, perda do meio ambiente equilibrado, apurado através da EPIA/RIMA, competindo ao órgão licenciador fixar o quantum da compensação, representado por uma contrapartida financeira ou de outra natureza, decorrente do desenvolvimento de um empreendimento ou de uma atividade econômica, de acordo com a compostura do impacto ambiental a ser dimensionado no relatório ( MOTA, Mauricio. Rio de Janeiro: Elsevier, 2009. p. 10)22

O princípio do usuário pagador e a compreensão da natureza jurídica da contraprestação da outorga onerosa do direito de construir como uma compensação urbanística

Sendo o meio ambiente ecologicamente equilibrado considerado bem de uso comum do povo, conforme a Constituição Federal, caracteriza-se como um interesse difuso. Ocorre que os recursos naturais livremente apropriáveis e, portanto, gratuitos, geram, sob a ótica da teoria econômica, falhas de mercado geradoras de externalidades.

Desta forma tem se procurado utilizar instrumentos econômicos como meio de internalização daquelas externalidades, ou seja, mecanismos por meio dos quais os custos

\footnotetext{
21 Ibidem. p. 8-9.

22 MOTA, Mauricio. Função socioambiental da propriedade: a compensação ambiental decorrente do princípio do usuário pagador na nova interpretação do Supremo Tribunal Federal. In: MOTA, Mauricio (Org.) Função Social do Direito Ambiental. Rio de Janeiro: Elsevier, 2009. p. 10.
} 
ambientais das atividades produtivas sejam absorvidos pelas próprias atividades (MOTA, Mauricio. Rio de Janeiro: Elsevier, 2009. p. 11) ${ }^{23}$.

As inúmeras intervenções no ambiente natural, em razão das atividades econômicas produtivas para satisfação das crescentes demandas, rompem com a possibilidade natural de equilíbrio ecossistêmico. Consequentemente, isto gera um consumo excessivo de recursos naturais, com uma descarga de materiais poluentes e sobrecarga de imposições para a sociedade, tornando os efeitos irreversíveis.

Sendo assim, o princípio do poluidor pagador ultrapassa a visão meramente retributiva e economicista do princípio, que passa a assumir propósitos maiores, a partir de uma dimensão ética de prevenção dos danos ambientais e manutenção das condições de vida no planeta.

Apesar dos processos produtivos dependerem dos bens naturais, não levam em conta os custos de tal utilização. Nesse caso existe uma falha de mercado geradora de externalidades negativas, que são situações em que a atividade de uma unidade econômica prejudica ou beneficia outras, de forma que terceiros ganham sem pagar por seus benefícios marginais ou perdem sem serem compensados por suportarem o malefício adicional.

Externalidades negativas, portanto, ocorrem no que concerne ao uso e consumo dos recursos naturais, desde que tal uso e consumo, por serem gratuitos, acabam por privar a sociedade de tal bem, sem qualquer contrapartida, e mais, transferem a essa mesma sociedade eventuais custos de prevenção e reparação do dano ambiental (SILVA FILHO, Carlos da Costa. Rio de Janeiro, 2008. p. 87) ${ }^{24}$.

A busca de internalizar estes custos sociais e ambientais levou à adoção no direito ambiental do princípio do poluidor-pagador, entendido como o princípio pelo qual "os poluidores são chamados a suportar o custo dos recursos ambientais que utilizam, de forma a que esses sejam geridos e utilizados de maneira a não onerar toda a sociedade" (ARAGÃO, Maria Alexandra de Sousa. 1997, p. 115) $)^{25}$

Na mesma linha de pensamento se encontra Ricardo Bosquesi:

23 MOTA, Mauricio. Função socioambiental da propriedade: a compensação ambiental decorrente do princípio do usuário pagador na nova interpretação do Supremo Tribunal Federal. In: MOTA, Mauricio (Org.) Função Social do Direito Ambiental. Rio de Janeiro: Elsevier, 2009. p. 11.

24 SILVA FILHO, Carlos da Costa. O princípio do poluidor-pagador: da eficiência econômica à realização da justiça. In: MOTA, Mauricio (Coord.) Fundamentos teóricos do direito ambiental. Rio de Janeiro: Elsevier, 2008. p. 87.

25 ARAGÃO, Maria Alexandra de Sousa. O princípio do poluidor-pagador: pedra angular da política comunitária do ambiente. Coimbra: Coimbra, 1997, p. 115. 
A contrapartida se justifica em relação a dois pontos, que ora se apresentam numa relação conjuntiva, ora numa relação disjuntiva. A primeira justificativa é que a contrapartida atua como mecanismo de indenização ao Poder Público, ou seja, da própria coletividade, quanto ao adensamento proporcionado pelo particular, em virtude do aumento de construção. Portanto, o recurso proveniente da contrapartida age na correção do adensamento urbano, às expensas do causador do "adensamento". A segunda justificativa prende-se ao princípio da justa distribuição do benefício e encargo da atividade urbanística. Visa-se corrigir as externalidades negativas do mercado imobiliário, evitando que o particular se aproprie das "mais valias" em seu imóvel, resultante de obras públicas ou se beneficie de favor legal, decorrente do plano urbano e outras leis de cunho urbanístico. Neste último caso, nota-se que, por circunstâncias específicas da cidade e por razões técnicas que nortearam a elaboração do Plano Diretor, no âmbito da opção dos instrumentos e índices construtivos disponíveis ao adequado ordenamento da cidade, algumas áreas passam a ganhar maior relevo econômico que outras, valorizando-se em relação às demais. [...] Por isto que o fundamento da contrapartida (e do solo criado, por conseguinte) não pode ficar adstrito, tão somente, como instrumento de solução do adensamento urbano. Esta circunstância caracteriza o ponto disjuntivo das justificativas quanto à imposição da contrapartida. Se em determinadas hipóteses se possa chegar à conclusão acima, ainda assim se justificaria a imposição da contrapartida na aplicação do instituto do solo criado. Neste caso, seu papel seria agir como instrumento de correção, ao menos atenuante, das externalidades negativas do mercado imobiliário, evitando-se, assim, a especulação. Nestes termos, a contrapartida se funda na promoção de isonomia, como instrumento de justa repartição dos encargos e benefícios, que eventualmente possam decorrer da atividade urbanística. Se pelo plano urbano é possível construir além de determinado coeficiente, que elevará o valor do imóvel, deve-se pagar um preço por isto, tanto para que o recurso auferido retorne em obras de infra-estruturas ou outras finalidades urbanísticas, bem como para evitar locupletamento do particular decorrente da lei. [...] Visa-se, com isto, evitar que determinadas pessoas se apropriem da valorização imobiliária sem que tenham praticado qualquer esforço por isto, sendo meramente agraciados por favor legal, tal como o planejamento urbano ou de atividade Estatal urbanística, como obras de infra-estruturas. Concluindo, a contrapartida atua na correção do mercado imobiliário, no sentido de devolver à coletividade o benefício patrimonial e proporcionar isonomia entre os diversos proprietários de imóveis urbanos, além de poder, separadamente ou em conjunto, indenizar a coletividade pela perda social advinda do adensamento urbano, já que a construção além de certo coeficiente poderá também acarretar este mal, provocando a saturação dos serviços e equipamentos urbanos. (BOSQUESI, Ricardo. São Paulo, 2006. p. $59-61)^{26}$

\footnotetext{
${ }^{26}$ BOSQUESI, Ricardo. Outorga onerosa do direito de construir. 2006. 94 f. Dissertação (Mestrado em Direito) - Faculdade de Direito, Pontifícia Universidade Católica de São Paulo, São Paulo, 2006. p. 59-61.
} 
No mesmo sentido Victor Carvalho Pinto, quando afirma que "externalidades são situações em que a atividade de uma unidade econômica prejudica ou beneficia outras unidades. No primeiro caso, a externalidade é negativa. No segundo, positiva. As externalidades negativas apresentam uma distribuição dos custos da atividade econômica para unidades que dela não se beneficiam. [...]. As externalidades negativas e positivas podem ser exemplificadas respectivamente pela poluição ambiental e pela valorização imobiliária decorrente de obras públicas. As atividades poluidoras acarretam um custo representado pelos gastos em saúde e em recuperação ambiental. São custos gerados pela atividade poluidora, mas que não se refletem no preço do produto final ou nos cálculos da unidade produtora. [...] A alta densidade encontrada nas cidades também é responsável por inúmeras externalidades nelas presentes. São muitas as atividades que produzem ruídos, odores, tráfego, poluição do ar ou das águas, erosão, etc. Além disso, a presença de uma edificação pode retirar a insolação, a vista, o acesso ou a aeração de outra. Ao mesmo tempo, as obras públicas e privadas valorizam os imóveis vizinhos, sem que sejam deles cobradas (PINTO, Victor Carvalho. São Paulo, 2010. p. 49) ${ }^{27}$.

O princípio significa que o poluidor deve suportar os custos da adoção de medidas impostas pelas autoridades públicas para assegurar que o meio ambiente se mantenha em um estado aceitável. Desta forma, o princípio do poluidor pagador não se contém em uma simples finalidade redistributiva, mas desponta como direito fundamental, para assumir uma função preventiva. Os encargos decorrentes da aplicação prática do princípio do poluidor pagador são embutidos nos preços dos produtos e repercutidos em direção ao consumidor final, contrapondose ao princípio do ônus social.

A mesma ratio iuris que informa a natureza jurídica da compensação ambiental como uma obrigação econômica de reparação pelo uso do meio ambiente, entendido este como um direito difuso de todos a determinada qualidade de vida e à preservação do meio ambiente ecologicamente equilibrado pode ser utilizada para compreender a natureza jurídica da contraprestação da outorga onerosa do direito de construir como uma compensação urbanística, ou seja, também obrigação econômica do proprietário em relação aos demais utentes da cidade em razão do acréscimo de investimentos públicos para suportar o adensamento adicional acarretado pelo empreendimento, entendido que todos devem ter o mesmo direito difuso à qualidade de vida na cidade, ao usufruto em igualdade de condições da função social da cidade.

${ }^{27}$ PINTO, Victor Carvalho. Direito urbanístico, planodiretor e direito de propriedade. 2. ed.São Paulo:RT, 2010. p. 49. 
Isso porque a outorga onerosa foi elaborada para atender à função social da propriedade e da cidade, sendo que a função social da propriedade implica transformação destinada a incidir diretamente sobre o fundamento dos direitos do proprietário e especificamente no conteúdo e no exercício desse direito. O enfoque passou a ser direcionado à sociedade e não ao proprietário do bem, titular desse direito, de forma que a função social orienta a coletividade e exige do proprietário o exercício do direito de forma a atender esse aspecto social.

Seguindo este raciocínio, a compensação urbanística é o instituto que prevê mecanismos compensatórios quando da realização de empreendimento acima do potencial construtivo básico previsto na outorga onerosa, em razão do acréscimo de investimentos públicos para suportar o adensamento adicional e do uso individualizado de um bem difuso.

Os direitos relacionados à função social da cidade e à função social da propriedade propõem uma nova visão de direitos e de como protegê-los. A percepção de que os direitos têm custos, de que os bens são esgotáveis e a noção de um direito difuso de todos ao meio ambiente urbano adequado e equitativo são questões vistas como importantes. Desta maneira, cada vez mais exaustiva se torna a preocupação de uma justa medida do uso dos bens, que muitas vezes não conseguem ser resguardados pelos instrumentos jurídicos disponíveis.

A lógica da natureza jurídica da contraprestação decorre, fundamentalmente, do reconhecimento de que a propriedade possui uma função social, capaz de instruir e conformar a noção de usuário pagador. A função social da propriedade funcionaliza o exercício do direito de propriedade a interesses extraproprietários, entendendo-se que os custos devem integrar previamente a própria concepção do direito subjetivo.

A linha de pensamento aqui levada adiante segue a mesma lógica que orienta o princípio da compensação ambiental e do usuário pagador. Quando o particular solicita e compra um potencial adicional construtivo acima do coeficiente básico, está fruindo de um direito difuso e desfazendo o equilíbrio entre área pública e privada, e sobrecarregando o Estado.

Acontece que, como já observado, ao ser concedida licença para construções acima do potencial básico, ocorre uma falha de mercado geradora de externalidade, pois os direitos têm custos, os quais não deveriam ser usufruídos de forma particular com ônus gerais.

A maneira encontrada de internalização do uso de um direito de todos e da sobrecarga do Estado pelo suporte na infraestrutura da localidade foi a cobrança da contraprestação pelo adicional construtivo. A percepção da necessidade de internalização dos custos sociais do potencial construtivo concedido a um particular em detrimento de toda sociedade, retirando desta o 
usufruto dos bens e onerando-a com a reposição da infraestrutura, fez com que a lei autorizasse o Poder Público a cobrar pelo benefício, pois a ausência dos custos de uso de um bem coletivo se assemelharia a um enriquecimento sem causa. Desta forma, o pagamento é devido como reflexo do princípio da igualdade perante os encargos públicos.

Sendo assim, os encargos decorrentes da aplicação prática do princípio do poluidor pagador são embutidos nos preços dos produtos e repercutidos em direção ao consumidor final, o beneficiário, como uma forma de assunção partilhada da responsabilidade social. Da mesma forma, o beneficiário do potencial adicional de construção terá de, na qualidade de beneficiário, pagar um preço pela maior pressão que gera sobre a infraestrutura urbana.

Embora os bens sociais da cidade tenham titularidades específicas - públicas ou particulares, em razão da função social da propriedade, são de utilização comum de todos, sendo de responsabilidade de todos compartilhar as despesas para conservação. Se de alguma forma alguém vem a utilizar os recursos ou a afetar o sistema social da cidade mais intensamente, a ponto de construir empreendimento que cause externalidades, cabe a este, na proporção da atividade por ele despendida - que pode ser apurada através de Estudo de Impacto de Vizinhança e/ou de Impacto Ambiental -, compensar, na medida de sua utilização maior e diferenciada, os demais.

Considerando, portanto, a função social da propriedade, e correlacionando-a com o instituto da compensação, do princípio do usuário pagador e das externalidades negativas, verificase que o direito de propriedade deverá ser exercido em função do direito de toda a coletividade a um meio ambiente ecologicamente equilibrado.

A compensação urbanística, assim como a compensação ambiental, não decorre da contrariedade absoluta à norma jurídica, quando então se pode falar em ato ilícito stricto sensu e responsabilidade civil, mas sim da desconformidade para com o fim econômico-social para o qual o direito de propriedade foi instituído.

Como os direitos têm custos, como esses custos fazem parte do conteúdo do direito, e como a propriedade tem uma função social, correlacionada e funcionalizada ao direito difuso de todos à qualidade de vida equitativa na cidade, deve-se valorar o custo desse direito difuso, atingido pelo uso desmesurado de um em detrimento dos outros, e compensá-lo devidamente.

Consoante essa específica compreensão da compensação urbanística e do princípio do usuário pagador, de acordo com as externalidades negativas a eles correlatas, o utilizador do 
recurso ou promotor do impacto deve suportar o conjunto dos custos destinados a tornar possível a utilização do recurso.

A compensação urbanística tem por objetivo fazer com que esses custos não sejam suportados nem pelo Poder Público, nem por terceiros, mas pelo utilizador. E o custo real do impacto urbanístico deve ser apurado consoante os estudos de impacto a serem analisados pelo Município, conforme exigido pelo Estatuto da Cidade em seu artigo 4ํㅡ, inc. VI.

Da mesma forma que a compensação ambiental, a compensação urbanística engendra uma obrigação que pode ser cumprida sem que recursos do empreendedor sejam recolhidos diretamente ao erário. Após quantificada em dinheiro essa obrigação, ela pode ser cumprida diretamente pelo empreendedor, pois a contrapartida ao Poder Público pode ser paga em valor monetário ou de outra forma que dispuser a lei municipal específica, como a doação de áreas para parques e escolas, numa tentativa de equilíbrio entre as áreas públicas e privadas.

A compensação deve ser fixada proporcionalmente ao impacto para a sociedade tanto com a usurpação de um bem coletivo, quanto para compensação de áreas públicas e privadas e suporte de infraestrutura. Compete ao órgão licenciador fixar o quantum da compensação, que pode ser fixado de acordo com o Relatório de Impacto de vizinhança e Impacto Ambiental previstos no artigo 4으, inc.VI, do Estatuto da Cidade.

Assim, o próprio Município é que fixará o valor da contraprestação. Conforme o art. 30 do Estatuto da Cidade, o Município é que determina a fórmula de cálculo e a contrapartida, e a fórmula de cálculo deve ser baseada no relatório de impacto de vizinhança.

Desta forma, a configuração aqui proposta parece estar de acordo com os arts. 2o e 4으 do Estatuto da Cidade, ao determinar que a política urbana tem por objetivo ordenar o pleno desenvolvimento das funções sociais da cidade e da propriedade urbana. Por todas estas razões, chega-se à conclusão neste trabalho de que a natureza da contrapartida da outorga onerosa é a de uma contraprestação compensatória urbanística.

\section{CONCLUSÃO}

Em desfecho, é conveniente recapitular, em síntese esquemática, as principais considerações e conclusões expostas ao longo deste estudo. O presente trabalho se propôs a estudar o tema da outorga onerosa do direito de construir, instituto positivado na Lei n. 10.257, de 10 de julho de 2001 (Estatuto da Cidade), artigos 28 a 31, e definir a natureza jurídica da outorga e da contraprestação exigida no caso de deferimento desta. 
Foi demonstrado que o instituto da outorga onerosa do direito de construir veio contribuir para a noção de funcionalização da propriedade e para a extinção de noções individualistas e historicamente ultrapassadas a respeito da mesma.

Por muito tempo, prevaleceu a noção de direito de propriedade inspirada na Revolução Francesa. Evidentemente que a total liberdade em relação à propriedade, em um primeiro momento, era necessária para evitar os abusos cometidos, correspondendo à quebra de um sistema de exploração da maioria pela minoria. Mas, com o passar do tempo, com o aumento da população e, consequentemente, o aumento das necessidades sociais, a interpretação que se fazia do direito de propriedade já não era satisfatória como outrora, em especial diante da acumulação capitalista dos bens de produção, produzindo quebra dos princípios da própria revolução matriz e originando desigualdades e exploração.

Ocorreu uma evolução na noção de propriedade como direito natural para desembocar modernamente na ideia de propriedade função social. Já não permanece na legislação contemporânea o absolutismo pernicioso que dominava o direito de propriedade, nem prerrogativas que garantiam o exercício do direito sobre o bem em detrimento da coletividade. A propriedade tende cada vez mais a se subordinar ao bem comum e as inúmeras restrições e limitações que se fazem hoje ao seu livre exercício imprimem à propriedade um caráter mais dinâmico e justo, estando o direito de ter propriedade cada vez mais ligado à noção de boa gestão em um valor social de bem comum, a saber, o bem-estar coletivo.

O direito a cidades sustentáveis é de fato um direito fundamental das populações urbanas. É esse direito que deve prevalecer em toda a política urbana. Deve haver uma harmonia entre o bem-estar dos cidadãos e o desenvolvimento da cidade. É preciso conciliar, no exercício do direito de propriedade, vantagens individuais do proprietário e benefícios sociais e ambientais, a fim de que tal direito receba proteção constitucional.

No presente trabalho se procurou estabelecer a diferença entre a outorga onerosa do direito de construir e o solo criado. Quanto ao instituto da outorga onerosa do direito de construir, procura o direito, através dele, conciliar desenvolvimento com responsabilidade social. Existe uma preocupação que se sobrepõe ao interesse do particular e a interesses especulativos: há a preocupação com o bem-estar social, com a reversão de um custo adicional imposto à sociedade, sendo que este custo deve ser compensado de alguma forma. Por este motivo, veio o Estatuto da Cidade positivar a outorga onerosa do direito de construir. 
No que pertence à natureza jurídica do instituto, foram analisados o poder de polícia, a intervenção do Estado na propriedade, a limitação administrativa e a licença, em especial a licença para construir, para chegar-se à conclusão de que a outorga se trata de uma limitação administrativo-urbanística para regular a propriedade urbana, adequando-a aos fins sociais.

Por fim, decidiu-se o trabalho presente pela natureza da contraprestação da outorga onerosa como compensação urbanística, em analogia estreita com o conceito de compensação ambiental, conforme entendido pela doutrina e segundo o Supremo Tribunal Federal, pois a natureza jurídica da contraprestação urbanística da outorga onerosa pode muito bem ser entendida com base no desenvolvimento dos princípios da compensação ambiental.

Concluiu-se que a mesma ratio iuris que informa a natureza jurídica da compensação ambiental como uma obrigação econômica de reparação pelo uso do meio ambiente, entendido este como um direito difuso de todos a determinada qualidade de vida e à preservação do meio ambiente ecologicamente equilibrado pode ser utilizada para compreender a natureza jurídica da contraprestação da outorga onerosa do direito de construir como uma compensação urbanística, ou seja, também obrigação econômica do proprietário em relação aos demais utentes da cidade em razão do acréscimo de investimentos públicos para suportar o adensamento adicional acarretado pelo empreendimento, entendido que todos devem ter o mesmo direito difuso à qualidade de vida na cidade, ao usufruto em igualdade de condições da função social da cidade.

\section{REFERÊNCIAS}

ALOCHIO, Luiz Henrique Antunes. Do solo criado, outorga onerosa do direito de construir: instrumento de tributação para a ordenação do ambiente urbano. Rio de Janeiro: Lúmen Juris, 2005.

ALVES, Alexandre Ferreira de Assumpção. Direito edilício e a competência exclusiva dos Municípios. Disponível em:<http://www.buscalegis.ufsc.br/revistas/files/anexos/8763-8762-1-PB.pdf. > Acesso em: 05 mar. 2012.

AMARO, Luciano. Direito tributário brasileiro. 17 ed. São Paulo: Saraiva, 2011.

ARAGÃO, Alexandre Santos. Direito dos serviços públicos. 2 ed. Rio de Janeiro: Forense, 2008.

ARAGÃO, Maria Alexandra de Sousa. O princípio do poluidor-pagador: pedra angular da política comunitária do ambiente. Coimbra: Coimbra Editora, 1997.

BITENCOURT, Ana Paula Mota. A transferência do direito de construir para a conservação do Patrimônio Natural e Cultural: a experiência da cidade de Curitiba. p. 2. Disponível em: 
<http://www.ibdu.org.br/imagens/ATransferenciadoDireitodeConstruir.pdf> Acesso em: 05 mar. 2012.

BRASIL. Supremo Tribunal Federal. Pleno. Ação Direta de Inconstitucionalidade no 3.378-DF. Relator: Ministro Carlos Ayres Britto. Acórdão de 08 de abril de 2008. DJ n. 112, 20/06/2008. Disponível em: <http://www.stf.jus.br. > Acesso em: 10 maio 2012.

BONAVIDES, Paulo. Ciência política. 10 ed. São Paulo: Malheiros, 1999.

BOSQUESI, Ricardo. Outorga onerosa do direito de construir. 2006. 94 f. Dissertação (Mestrado em Direito) - Faculdade de Direito, Pontifícia Universidade Católica de São Paulo, São Paulo, 2006.

CARVALHO FILHO, José dos Santos. Comentários ao Estatuto da Cidade. 3 ed. Rio de Janeiro: Lumen Juris, 2009.

Manual de direito administrativo. 17 ed. Rio de Janeiro: Lumen Juris, 2007.

CAVEDON, Fernanda de Salles. Função social e ambiental da propriedade. Florianópolis: Visualbooks, 2003.

DI PIETRO, Maria Sylvia Zanella. Direito administrativo. 15 ed. São Paulo: Atlas, 2003.

DUGUIT, Leon. Las transformaciones del derecho publico y privado. Buenos Aires: Editorial Heliasta, 1975.

FALLA, Fernando Garrido. Tratado de derecho administrativo. v. II. 10 ed. Madrid: Tecnos, 1992.

FARIA, Cristiano Chaves de; ROSENVALD, Nelson. Direitos reais. 3 ed. Rio de Janeiro: Lumen Juris, 2006.

FIGUEIREDO, Lucia Valle. Disciplina urbanística da propriedade. São Paulo: Malheiros, 2005.

GASPARINI, Diógenes. O Estatuto da Cidade. São Paulo: NDJ, 2002.

GORDILLO, Agustín. Tratado de derecho administrativo: la defensa del usuario y del administrado. Tomo 2. 8 ed. Buenos Aires: Fundación de Derecho Administrativo, 2006.

GRAU, Eros Roberto. Direito urbano, regiões metropolitanas, solo criado, zoneamento e controle ambiental, projeto de lei de desenvolvimento urbano. São Paulo: Revista dos Tribunais, 1983.

GROCIO, Hugo. De la libertad de los mares. Tradución de V. de Blanco y L. García Arias. Madrid: Centro de Estudios Constitucionales, 1979.

HEGEL, George Wilhelm Friedrich. Princípios da filosofia do direito. São Paulo: Martins Fontes, 1997.

HOBBES, Thomas. Leviatã ou matéria, forma e poder de um Estado eclesiástico e civil. São Paulo: Martin Claret, 2004. 
KASER, Max. Direito privado romano. Lisboa: Calouste Gulbenkian, 1999.

LOCKE, John. Segundo tratado sobre o governo: ensaio relativo à verdadeira origem, extensão e objetivo do governo civil. São Paulo: Martin Claret, 2005.

MACEDO, Marina Michel de. Operação urbana consorciada: uma alternativa para a urbanificação das cidades. 2007. 199 f. Dissertação (Mestrado em Direito) - Faculdade de Direito, Universidade Federal do Paraná, Curitiba, 2007.

MACHADO, Hermano Augusto. A função social e a tipificação no direito de propriedade. Estudos jurídicos em homenagem à Faculdade de Direito da Bahia. São Paulo: Saraiva, 1981.

MACHADO, Hugo de Brito. Curso de direito tributário. 27 ed. São Paulo: Malheiros, 2006.

MEDAUAR, Odete. Direito administrativo moderno. São Paulo: Revista dos Tribunais, 1999.

MELLO, Celso Antônio Bandeira de. Curso de direito administrativo. 12 ed. São Paulo: Malheiros, 2000.

MOREIRA NETO, Diogo de Figueiredo. Introdução ao direito ecológico e ao direito urbanístico. 2. ed. Rio de Janeiro: Forense, 1977.

MOTA, Mauricio (Org.) Função Social do Direito Ambiental. Rio de Janeiro: Elsevier, 2009.

MOZOS, José Luís de los. El derecho de superfície en general y en relación con la planificación urbanística. Madrid: Ministério de la Vivienda, 1974.

PAULSEN, Leandro. Curso de direito tributário completo. 4 ed. Porto Alegre: Livraria do Advogado, 2012.

PEREIRA, Caio Mario da Silva. Instituições de Direito Civil. 12 ed. Vol. IV. Rio de Janeiro: Forense, 1995.

PINTO, Victor Carvalho. Direito urbanístico, plano diretor e direito de propriedade. São Paulo: RT, 2005.

ROUSSEAU, Jean-Jacques. Discurso sobre a origem e os fundamentos da desigualdade entre os homens. São Paulo: Escala, 2007. p. 57.

Do contrato social. São Paulo: Martin Claret, 2004.

SAHD, Luiz Felipe Netto de Andrade e Silva. Considerações sobre o fundamento moral da propriedade. Kriterion: Revista de Filosofia, Belo Horizonte, n. 115, 2007. Disponível em <http://www.scielo.br/scielo.php?pid=S0100-512X2007000100013\&script=sci_arttext\&tlng=en> Acesso em: 16 mar. 2011.

SAVATIER, René. Du droit civil au droit public. 2 ed.Paris: LGLD, 1950.

SCHOUERI, Luís Eduardo. Direito tributário. São Paulo: Saraiva, 2011. 
SILVA FILHO, Carlos da Costa. O princípio do poluidor-pagador: da eficiência econômica à realização da justiça. In: MOTA, Mauricio (Coord.) Fundamentos teóricos do direito ambiental. Rio de Janeiro: Elsevier, 2008.

SILVA, José Afonso da. Direito urbanístico brasileiro. 6 ed. São Paulo: Malheiros, 2010.

TEPEDINO, Gustavo. A tutela da propriedade privada na ordem constitucional. Revista da Faculdade de Direito da UERJ, Rio de Janeiro, vol. 1, 1993.

TORRES, Marcos Alcino. Impacto das novas idéias na dogmática do direito de propriedade. A multiplicidade dominial. In: MOTA, Mauricio; TORRES, Marcos Alcino (Coord.). Transformações do direito de propriedade privada. Rio de Janeiro: Elsevier, 2009.

A propriedade e a posse: um confronto em torno da função social. 2 ed. Rio de Janeiro: Lumen Juris, 2008.

TORRES, Ricardo Lobo. Tratado de direito constitucional financeiro e tributário. Vol. IV. Rio de Janeiro: Renovar, 2007.

Curso de direito financeiro e tributário. 5. ed. Rio de Janeiro: Renovar, 1998.

Trabalho enviado em 14 de agosto de 2015.

Aceito em 29 de janeiro de 2016. 